\title{
Actual problems of exposure risk assessment of finely dispersed aerosols and aerosols of nanoparticles
}

\author{
A. I. Sevalnev ${ }^{1}$, L. P. Sharavara ${ }^{1}$, 0. 0. Nefedov $^{2}$, 0. 0. Nefedova ${ }^{2}$, V. F. Shatorna ${ }^{2}$ \\ ${ }^{1}$ Zaporizhzhia State Medical University, Ukraine, ${ }^{2}$ Dnipropetrovsk medical Academy of Ministry of health of Ukraine, Dnipro
}

Key words:

nanoparticles, finely dispersed particles, working zone air, occupational risk.

\section{Zaporozhye}

medical journal

2018; 20 (2), 270-274

DOI:

10.14739/2310-1210

2018.2.125526

E-mail:

saravaralarisa@

gmail.com
Purpose of the study - analysis of the scientific literature on generalization of the data on domestic and foreign experience in risk assessment due to exposure to finely dispersed aerosols and aerosols of nanoparticles (NPs).

The article summarizes data of long-term studies on the effect of nanomaterials and nanoparticles on the quality of human habitat and health. The domestic and foreign experience of harm health assessment, safety of new types of nanomaterials for the environment and work-related conditions have been analyzed.There are numerous studies of foreign and domestic scientists on the biological activity of nanoparticles and their effect on experimental animals, namely, on the specificity of their effect on various organs and systems of the body. Classification of nanomaterials, depending on their chemical composition, is presented. Attention is paid to the problems of nanosafety, namely, to the evaluation of nanotoxicity of substances and to the definition of the concept of a "dose" for nanoparticles. The data on the presence of finely dispersed and ultra-fine particles in the atmospheric air, which increase risk of respiratory system diseases among residents of large megacities, is given. There is special importance on assessing work conditions and occupational risks in production and use of materials which contain nanoparticles as well as in production processes with formation of the fine dust and nanoparticles indicated in the article. Due to the lack of a clear system for assessing health risks related to the action of nanoparticles, lack of common criteria of harmfulness and maximum allowable concentrations for most nanoparticles and uniform methods of their control, it is suggested to strictly adhere to protective measures in contact with nanomaterials and active improvement of nanosecurity measures.

Conclusions. High toxicity and health hazards of finely dispersed and ultra-fine particles confirm need to control their content in the air of the populated areas and in the air of the working zone of industrial enterprises, where suspended particles are formed in the technological process. Obtained results of the scientific studies should be used for substantiation of preventive measures on nanosecurity in development and implementation of the nanotechnology, in order to protect health of workers and the general population.
Киючові слова: наночастки, арібнодисперсні частки, повітря робочої зони, професійний ризик.

\section{Запорізький} медичний

журнак. - 2018. T. 20, № 2(107). -

C. 270-274

\section{Актуальні питання оцінювання ризику впливу високодисперсних аерозолів та аерозолів наночасток}

\author{
А. І. Севальнєв, А. П. Шаравара, О. О. Нефьодов, О. О. Нефьодова, В. Ф. Шаторна
}

Мета роботи - аналіз наукової літератури для узагальнення відомостей про вітчизняний і закордонний досвід оцінювання ризику від впливу високодисперсних аерозолів та аерозолів наночасток.

Узагальнили матеріали багаторічних досліджень впливу наноматеріалів і наночастинок на якість середовища проживання людини та на її здоров'я. Проаналізували вітчизняний і закордонний досвід оцінювання шкоди для здоров'я, безпеки нових видів продукції наноматеріалів для довкілля та виробничого середовища. Наведені численні дослідження закордонних і вітчизняних учених щодо біологічної активності наночастинок і їхнього впливу на експериментальних тварин, зокрема особливості впливу на різні органи, системи організму. Подано класифікацію наноматеріалів залежно від хімічного складу. Приділено увагу проблемам нанобезпеки, зокрема оцінюванню нанотоксичності речовин і визначенню поняття «доза» для наночастинок. Наведені відомості щодо наявності в атмосферному повітрі дрібнодисперсних, ультратонких частинок, які підвищують ризик захворювань респіраторної системи в жителів мегаполісів. Наголошено на особливій важливості оцінювання умов праці та професійного ризику під час виробництва й застосування матеріалів, що містять наночастинки, а також виробничих процесів з утворенням дрібнодисперсного пилу та наночастинок. У зв'язку з відсутністю чіткої системи оцінювання ризиків для здоров'я від дії наночасток, єдиних критеріїв шкідливості та гранично допустимих концентрацій для більшості наночастинок та єдиних методів їх контролю запропоновано чітке дотримання методів захисту під час контакту із наноматеріалами та активне вдосконалення заходів із нанобезпеки.

Висновки. Висока токсичність і небезпека для здоров'я дрібнодисперсних та ультратонких частинок підтверджує необхідність організації контролю їх вмісту в повітрі населених пунктів і повітрі робочої зони промислових підприємств, у технологічному процесі яких утворюються зважені частинки. Результати наукових досліджень необхідно використовувати для обґрунтування профілактичних заходів нанобезпеки під час розробки та реалізації нанотехнологій для охорони здоров'я працівників і населення загалом.
Киючевые слова: наночастицы, мелкодисперсные частицы, возаух рабочей зоны, профессиональный риск.

\section{Актуальные вопросы оценки риска воздействия высокодисперсных аэрозолей и аэрозолей наночастиц}

\author{
А. И. Севальнев, А. П. Шаравара, А. А. Нефедов, Е. А. Нефедова, В. Ф. Шаторная
}

Цель работы - анализ научной литературы для обобщения данных об отечественном и зарубежном опыте оценки риска от воздействия высокодисперсных аэрозолей и аэрозолей наночастиц. 
Обобщены материалы многолетних исследований воздействия наноматериалов и наночастиц на качество среды обитания человека и на его здоровье. Проанализирован отечественный и зарубежный опыт оценки вреда здоровью, безопасности новых видов наноматериалов для окружающей и производственной среды. Представлены многочисленные исследования зарубежных и отечественных ученых биологической активности наночастиц и их влияния на экспериментальных животных, а именно особенности их воздействия на различные органы и системы организма. Представлена классификация наноматериалов в зависимости от химического состава. Уделено внимание проблемам нанобезопасности, а именно оценке нанотоксичности веществ и определению понятия «доза» для наночастиц. Приведены данные о наличии в атмосферном воздухе мелкодисперсных и ультратонких частиц, которые повышают риск заболеваний респираторной системы у жителей мегаполисов. Указана особая важность оценки условий труда и профессионального риска при производстве и применении материалов, содержащих наночастицы, а также производственных процессов с образованием мелкодисперсной пыли и наночастиц. В связи с отсутствием четкой системы оценки рисков для здоровья от действия наночастиц, единых критериев вредности и предельно допустимых концентраций для большинства наночастиц и единых методов их контроля, предлагается более строгое соблюдение мер защиты при контакте с наноматериалами и активное совершенствование мероприятий по нанобезопасности.

Выводы. Высокая токсичность и опасность для здоровья мелкодисперсных и ультратонких частиц подтверждает необходимость организации контроля их содержания в воздухе населенных мест и в воздухе рабочей зоны промышленных предприятий, в технологическом процессе которых образуются взвешенные частицы. Полученные результаты научных исследований необходимо использовать для обоснования профилактических мер нанобезопасности при разработке и реализации нанотехнологий для охраны здоровья работающих и населения в целом.

\section{Actuality}

Modern development of civilization is characterized by an unprecedented acceleration of the scientific and technological progress. Development of industry, innovative technologies and nanotechnology, in particular, is an absolute priority for the majority of countries.

In this regard, many new problems appear, which require clarification of the role of the scientific and technological progress in assessing its positive and negative consequences for the human health and the environment. The underestimation of the adverse side effects of the scientific and technological progress has already brought the world to the edge of the ecological crisis, associated with the environmental pollution, and reach now threatening proportions. Nanotechnology is likely to make a significant contribution to the environmental pollution $[1,2]$.

The development of nanotechnologies at the accelerated rate and their active introduction in industrial production will inevitably lead to a significant amount of nanoparticles (NPs), entering the environment. Accordingly, their increasing concentrations in the environmental objects pose a real threat to the human health. The study on occurring potential risks in the interaction of nanomaterials with man and the environment is an actual and important task today.

The purpose of the study to analyze scientific literature for summarizing data of domestic and foreign experience on risk assessment from the effects of finely dispersed aerosols and aerosols of NPs.

Modern nanotechnologies are of a great potential and, as it is said by experts, will fundamentally change the society in the 21 st century. However, new scientific achievements not only contribute to the development of the economy, improve the quality of the human life, but set a number of important tasks. Among them, impact of nanomaterials and NPs on the quality of the human habitat, animal and plant world, quality of agricultural products and water, and human health $[3,4]$.

There are both natural and anthropogenic sources of the environmental pollution with NPs. Natural sources of the NPs origin cover forest and steppe fires, volcanic emissions, dust raised from the water surface, viruses, biological subjects. The anthropogenic sources include do- mestic waste, mining processes, incineration of the waste, welding and soldering processes, fuel combustion, industrial production, construction, etc. Artificially formed NPs hardly biodegrade or digest in the environment.

Their harm can be associated with unusual properties of substances, namely mobility and resistance in soil, water, air, bioaccumulation, unpredictable interaction with chemical and biological materials $[5,6]$.

The problems of nanosecurity were formulated and actively developed by a number of international, governmental, intergovernmental and public organizations: WHO, FAO, OECD (Organization for Economic Cooperation and Development), EFSA (European Food Safety Authority, European Union), SCENIHR (Scientific Committee on Emerging and Newly Identified Health Risks, EU), DEFRA (Department for Environment, Food and Rural Affairs, United Kingdom), FSA(Food Standards Agency, United Kingdom), FDA(Food and Drug Administration, USA), US EPA (Environmental Protection Agency, USA), ISO (International Organization for Standardization), etc. [7].

Today, foreign and domestic scientists are conducting numerous studies on the biological activity of NPs on experimental animals, allowing to establish that nanocrystalline iron and zinc accelerate the growth of animals in biological doses; enhance liver regeneration [3]; intracheal administration of titanium nitride NPs promote developing structural changes in the lungs [8]; dystrophic changes are observed in the liver parenchyma in the action of lead sulfide [2]. In the works of foreign researchers it is found that macrophages, leukocytes, phagocytes do not recognize carbon nanotubes when they enter the lung tissue of animals, and that they do not perform the function of recycling alien particles. As a result, inflammation of the lung tissue takes place and development of malignant neoplasms [9-11].

In the literature, the action of NPs with a different diameter and specific surface is described. Thus, condensation aerosols of electrothermal origin cause formation of interstitial fibrosis in the inhalation dusting in animals; condensate of the gas-flame origin gives a rapid formation of the nodular fibrosis; action of silicon dioxide condensate causes the death of experimental rats [12].

It has been established that the main target organs in the inhalation pathway of NPs are lungs, blood vessels
Запорожский медицинский журнал. - 2018. T. 20, № 2(107). C. $270-274$ 
and heart [13]. It is known that the pathogenetic effect in the inhalation action of NPs on the human body is associated with the development of local pulmonary and systemic inflammation and the further increase of the coagulation activity in the circulatory bed [14].

Nanoparticles, circulating in the atmospheric air, can provoke exacerbation of available diseases of the bronchopulmonary system [12], increase the risk of mortality from diseases of the cardiovascular system [15], exert hepatotoxic and carcinogenic effect [16].

The analysis of the literature data shows that NPs have a higher toxicity than conventional microparticles; they can penetrate unchanged through the cellular barriers, circulate and accumulate in organs and tissues, causing more severe pathological lesions of internal organs (for example, granuloma formation in the lungs, cirrhosis of the liver, glomerulonephrosis), and, also, they are heavily excreted from the body [2,17-19]. In the nanosized state, any substances acquire new chemical, physical and biological properties: they have a large specific surface, high chemical potential, are of small size and of different form, have high adsorption activity and are able to accumulate.

To date, there is a classification of nanomaterials, depending on the chemical composition: metallic nanoparticles, nanoparticles of metal oxides and nonmetals, semiconductor nanoparticles, nanoparticles from organic polymers, quantum dots and nanoparticles of organically modified silicates.

Heavy metals are the most common chemical pollutants, which cover more than 40 chemical elements.

One of the problems of the increasing risk of the respiratory system diseases is large technogenic emissions into the atmospheric air, which contain ultrafine particles [14].

In recent years, in large megalopolises of the world, not the total content of substances weighed in atmospheric air is monitored, but the most dangerous fraction with a particle size of up to $10 \mu \mathrm{m}\left(\mathrm{PM}_{10}\right)$ [20]. In Ukraine, only the total amount of the suspended substances is determined in, both, atmospheric air and in the air of the working zone, and this does not give a complete picture on the composition of the air environment and, accordingly, on their effect on humans. The problems of the dust pollution of the urban environment are closely related on the health problems of residents of large megacities and are mainly considered in relation to the effect of different industries on the state of urban industrial ecosystems [21]. The analysis of the literature data show that the questions on the fractional composition of the urban dust and the dust in the air of the working zone, as well as the distribution of finely dispersed fractions in the air of residential and industrial zones, are being studied quite actively [22-27].

Of particular importance is the assessment of work conditions and occupational risk in the manufacture and use of materials, containing NPs, as well as production processes with formation of the fine dust and NPs.

One of the most important problems in the evaluation of nanotoxicity is the concept of a «dose»; there is still no unequivocal opinion on this issue. The total mass of NPs, their number, the general mass in the investigated volume, mass or object is used as the dose characteristic. The most appropriate method is to estimate the dose according to the general surface of a NP in a unit of volume. In the UK, there are recommended safety-oriented values for the con- tent of NPs in the air at workplace, which are expressed as a part of the existing limit of an occupational exposure to harmful substances (WELs - workplace exposure limits). Four categories of NPs were identified, sorted by nature and properties: fibrous nanomaterials, with a high content of insoluble forms - the estimated limit in the air of the workplace is $0.01 \mathrm{fiber} / \mathrm{ml}$; nanomaterials (CMAR), classified as mutagens, allergens, carcinogens and reproductive toxins - an assumed limit is $0,1^{*} \mathrm{WEL}$; insoluble nanomaterials an estimated limit of 0,066 * WEL; soluble nanomaterials tentative safety limit is $0,5^{*} \mathrm{WEL}$.

Practically all dust and gas emissions in the examined metallurgical, engineering and mining industries contain fine dust fractions up to $80 \%$ of $\mathrm{PM}_{10}$ and up to $40 \%$ of $\mathrm{PM}_{2.5}$. The disperse composition of the dust in the air of the working zone depends on the specificity of the technological process, raw materials and materials. In emissions of many technological processes there are particles of a nanoscale range, which require direct studies of their effect on workers. A large volume of scientific research confirms the presence of the fine dust and NPs in the air of the working zone of workers in various technological processes at metallurgical, mining, machine-building enterprises, in construction, etc. [24-27]. Modern international and domestic standards provide for using various methods and devices in monitoring the content of NPs, which are actively used today [28]. Now, due to the lack of a clear system for assessing health risks from NPs, common criteria of harmfulness and maximum allowable concentrations for most NPs, there is a need in more strict compliance of protective measures in contact with NPs and active improvement of measures on nanosecurity.

\section{Conclusions}

High toxicity and health hazards of finely dispersed and ultra-fine particles confirm the need to control their content in the air of the populated areas and in the air of the working zone at industrial enterprises, where, due to technological processes, suspended particles are formed.

The obtained results of the scientific research should be used to substantiate the preventive measures on nanosecurity in development and implementation of nanotechnology for protection the health of workers and the general population.

Perspectives of further research. Despite the fact that a great number of research is conducted today on the content of NPs in the air and on their impact on environmental objects and human health, further research is needed in this direction.

The problems of further research on the effect of NPs on the human body, development and implementation of necessary methods and control of nanoparticles, substantiation of safe levels of NPs in objects of the environment and in work condition, assessment of the health status and risk levels remain to be actual.

\section{References}

[1] Magidov, S. Kh. (2009). Razvitie sovremennykh nanotekhnolohij i profilakticheskaya medicina [Development of modern nanotechnologies and preventive medicine]. Zdorove i obrazovanie $v$ XXI veke. Proceedings of the 10th International Congress (P. 207-211). Moscow. [in Russian]. 
[2] Potapov, A. I., Rakitskiy, V. N., Tulakin, A. V., Lutsenko, L. A., Il'nitskaya, A. V., Egorova, A. M., \& Gvozdeva, L .L. (2013). Bezopasnost' nanochastic i nanomaterialov dlya okruzhayushchej i proizvodstvenoj sredy [Safety of nanoparticles and nanomaterials for environmental and occupational space]. Gigiena i sanitariya, 3, 8-14. [in Russian].

[3] Bogoslovskaya, O. A., Sizova, E. A., Polyakova, V. S., Miroshnikova, S. A., Leipunsky, I. O., Olkhovskaya, I. P., \& Glushchenko, N. N. (2009). Izuchenie bezopasnosti vvedeniya nanochastic medi s razlichnymi fiziko-khimicheskimi kharakteristikami v organizme zhivotnykh [Studying of safety of copper nanoparticles introduction with different physical- chemical characteristics into animals' organism]. Vestnik Orenburgskogo gosudarstvennogo universiteta, 2(108), 124-127. [in Russian].

[4] Demetska, O. V., Kozytska, T. V., Andrusishina, I. M., Movchan, V. O., Tkachenko, T. Yu., \& Grodzyuk, G. Ya. (2014) Otsinka potentsinoho ryzyku pry khimichnomu syntezi nanochastynok sulfidu kadmiiu [Assessment of potential risk in chemical synthesis of cadmium sulphide nanoparticles]. Ukrainskyi zhurnal z problem medytsyny pratsi, 4(41), 51-56 [in Ukrainian]

[5] Anciferova, I. V. (2012). Istochniki postupleniya nanochastic v okruzhayushchuyu sredu [Sources of nanoparticles inflow to the environment]. Vestnik Permskogo nacional'nogo issledovatel'skogo politekhnicheskogo universiteta. Mashinostroenie, materialovedenie, 14(2), 54-64 [in Russian].

[6] Nemenko, B. A., Il'iasova, A. D., \& Syzdykov, D. M. (2014). Metody opredeleniya vzveshenykh ae'rozolej v atmosfernom vozdukhe [Methods of definition of the weighed aerosols in atmospheric air]. Vestnik KazNMU, 2(2), 488-490. [in Russian]

[7] Onishchenko, G. G., Tutelyan, V. A., Gmoshinsky, I. V., \& Khotimchenko, S. A. (2013). Razvitie sistemy ocenki bezopasnosti i kontrolya nanomaterialov i nanotekhnologij v Rossijskoj Federacii [Development of the system for nanomaterials and nanotechnology safety in Russian Federation]. Gigiena i sanitariya, 1, 4-11 [in Russian]

[8] Yavorovsky, O. P., Solokha, N. V., Veremiy, M. I., Karlova, O. O., Bobyr, V. V., \& Chobotar, A. P. (2016). Hihienichna otsinka vurobnychykh chynnykiv yak osnova upravlinnia ryzykamy u roboti operatoriv z oderzhannia nanoporoshkiv nitrydu tytanu, dysylytsydu khromu i dioksydu tsyrkoniiu [Hygienic assessment of the production factors as a basis for risk management in the operators' work for the manufacture of titanium nitride, chromium disilicide, and zirconium dioxide nanopowders]. Dovkillia ta zdorovia, 8, 63-68 [in Ukrainian].

[9] Sharma, M., Nikota, J., Halappanavar, S., Castranova, V., Rothen-Rutishauser, B., \& Clippinger, A. J. (2016). Predicting pulmonary fibrosis in humans after exposure to multi-walled carbon nanotubes (MWCNTs). Arch Toxicol., 90(7), 1605-1627. doi: 10.1007/s00204-016-1742-7.

[10] Li, N., Xia, T., \& Nel, A. E. (2008). The role of oxidative stress in ambient particulate matter-induced lung diseases and its implications in the toxicity of engineered nanoparticles. Free Radic. Biol. Med., 44(9), 1689-1699. doi: 10.1016/j.freeradbiomed.2008.01.028.

[11] Mercer, R. R., Scabilloni, J. F., Hubbs, A. F., Battelli, L. A., McKinney, W., \& Friend, S. (2013). Distribution and fibrotic response following inhalation exposure to multi-walled carbon nanotubes. Part Fibre Toxicol., 10, 10-33. doi: 10.1186/1743-8977-10-33.

[12] Akimova, E. I. (2010). Gigienicheskie voprosy bezopasnosti razvitiya nanotekhnologij [Hygienic problems concerning the security of nanotechnologies development]. Zdorov'e naseleniya i sreda obitaniya, 2, 45-47. [in Russian].

[13] Stone, V., Miller, M. R., Clift, M. J. D., Elder, A., Mills N. L., Moller, P., et al. (2017). Nanomaterials Versus Ambient Ultrafine Particles: An Opportunity to Exchange Toxicology Knowledge. Environ Health Perspect, 125(10), 125-135. doi: 10.1289/EHP424.

[14] Zibarev, E. V., Tchashin, M. V., Nikonova, S. M., Kousrayeva, Z. S., Kouzmin, A. V., Ellingsen, D. G., \& Thomassen, Y. (2010). Ocenka biomarkerov e'kspozicii $k$ svarochnomu ae'rozolyu [Evaluating biomarkers of exposure to electric welding aerosol]. Medicina truda $i$ promyshlennaya e'kologiya, 4, 14-17 [in Russian].

[15] Shutt, R. H., Kauri, L. M., Weichenthal, S., Kumarathasan, P., Vincent, R., Thomson, E. M., et al. (2017). Exposure to air pollution near a steel plant is associated with reduced heart rate variability: a randomised crossover study. Environ Health, 1, 16-20. doi: 10.1186/ s12940-016-0206-0.

[16] Hajrullin, R. Z., \& Samarin, E. N. (2014). Osobennosti obespecheniia bezopasnykh uslovii truda rabotnikov predpriiatii nanoindustrii [Features of providing safe working conditions for workers of nanoindustry enterprises]. Vestnik Kazanskogo tekhnologicheskogo universiteta, 17(15), 331-333 [in Russian].

[17] Zaitseva, N. V., Zemlyanova, M. A., Zvezdin, V. N., \& Sayenko, Ye. V. (2013). Toksikologo-gigienicheskaya ocenka bezopasnosti vodnoj suspenzii nanodispersnogo dioksida kremniya, sintezirovanogo metodom zhidkokristallicheskogo templantirovaniya [Toxicological and hygienic safety assessment of the aqueous suspension of nano-dispersed silicon dioxide, synthesized using liquid-crystal templating]. Analiz riska zdorov'yu, 1, 65-72 [in Russian].
[18] Wang, C., Cheng, K., Zhou, L., He, J., Zheng, X., Zhang, L. et al. (2017). Evaluation of Long-Term Toxicity of Oral Zinc Oxide Nanoparticles and Zinc Sulfate in Mice. Biol Trace Elem Res., 178(2), 276-282. doi: 10.1007/s12011-017-0934-1.

[19] Hong, F., Zhou, Y., Zhou, Y., \& Wang, L. (2017). Immunotoxic effects of thymus in mice following exposure to nanoparticulate $\mathrm{TiO}_{2}$. Environ Toxicol., 32(10), 2234-2243. doi: 10.1002/tox.22439.

[20] Simonova, I. N., Antonyuk, M. V., \& Vitkina, T. I. (2013). Vliyanie nanochastic vozdushnoj sredy na sostoyanie bronkholegochnoj sistemy [The influence of nanoparticles from the air on the state of bronchopulmonary system]. Biulleten' fiziologii i patologii dykhaniya, 49, 115-120. [in Russian].

[21] Trokhimchuk, K. A. (2013). O vliyanii GRES na zagryaznennost' melkodispersnoj pul'yu gorodskikh territorij [Effect of state district power plant on pollution by fine particles of urban areas]. Al'ternativnaya e'nergetika i e'kologia, 12(134), 73-76 [in Russian].

[22] Ufimceva, L. V., Antipova, N. S., \& Kol'cova, E. E. (2015). Raspredelenie nanochastic pyli v vozdukhe selitebnoj territorii Khabarovska pod vliyaniem atmosfernykh osadkov [The dust nanoparticle distribution in the air of Khabarovsk residential territory under the atmospheric precipitation influence]. Vestnik KrasGAU, 5, 50-53. [in Russian]

[23] Sevalnev, A. I., \& Sharavara, L. P. (2016). Hihiienichna otsinka vmistu dribnodyspersnoho pylu u povitri robochoi zony pratsivnykiv metalurhiinoho pidpryiemstva povnoho tsyklu [Hygienic assessment of the content of fine dust in the air of the working zone of workers of a full-cycle metallurgical enterprise]. Suchasni medychni tekhnolohii, 3(31), 112-115. [in Ukrainian].

[24] Ulanova, T. S., Gileva, O. V., \& Volkova, M. V. (2015). Opredelenie chastic mikro-i nanodiapazona v vozdukhe rabochej zony na predpriyatiyakh gornodobyvayushchej promyshlennosti [Determination of micro and nanoparticles in the workplace area at the enterprises of mining industry]. Analiz riska zdorov'yu, 4, 44-49. [in Russian]

[25] May, I. V., Kokoulina, A. A., Zagorodnov, S. Y., \& Popova, E. V. (2014). Ocenka e'kspozicii naseleniya k melkodispersnoj pyli v zonakh vliyaniya promyshlennykh stacionarnykh istochnikov [Exposure assessment for population to fine particles in the influence zones of emissions from industrial stationary emission sources]. Analiz riska zdorov'yu, 1, 21-30. [in Russian].

[26] Onishchenko, G. G. (2011). Organizaciya nadzora za oborotom nanomaterialov, predstavlyayushchikh potencial'nuyu opasnost' dlya zdorov'ya cheloveka [Organizing the supervision over the turnover of nanomaterials presenting a potential hazard to human health]. Gigiena i sanitariya, 2, 4-9. [in Russian].

[27] Ulanova, T. S., Antipyeva, M. V., Zabirova, M. I., \& Volkova, M. V. (2015). Opredelenie chastic nanodiapazona v vozdukhe rabochej zony metallurgicheskogo proizvodstva [Determination of nanoscale particles in the air of working zone at the metallurgical production]. Analiz riska zdorov'yu, 1, 77-81. [in Russian].

[28] Yavorovsky, O. P., Veremey, M. I., Demetska, O. V., \& Zinchenko, T. O. (2013). Do pytannia hihiienichnoho kontroliu u povitri robochoi zony aerozoliv z nanorozmirnoiu dyspersnoiu fazoiu [On the issue of the hygienic control aerosols with nanoscale dispersed phase in the working area]. Dovkillia ta zdorovia, 1, 56-59. [in Ukrainian].

\section{Information about authors:}

Sevalnev A. I., MD, PhD, Associate Professor, Head

of the Department of General Hygiene and Ecology, Zaporizhzhia

State Medical University, Ukraine.

Sharavara L. P., MD, PhD, Senior Lecturer, Department of General Hygiene and Ecology, Zaporizhzhia State Medical University,

Ukraine.

Nefedov 0. 0., MD, PhD, Associate Professor,

Department of Pharmacology and Clinical Pharmacology,

SE "Dnipropetrovsk Medical Academy of the Ministry of Health of Ukraine", Dnipro.

Nefedova 0. O., MD, PhD, DSc, Associate Professor, Head of the Department of clinical anatomy, anatomy and operative surgery, SE "Dnipropetrovsk Medical Academy of the Ministry of Health of Ukraine", Dnipro.

Shatorna V. F., PhD, DSc, Professor, Head of the Department of Medical Biology, Pharmacognosy and Botany,

SE "Dnipropetrovsk Medical Academy of the Ministry of Health of Ukraine", Dnipro.

\section{Відомості про авторів:}

Севальнєв А. І., канА. меА. наук, Аоцент, зав. каф. загальної гігієни та екології, Запорізький державний меАичний університет, Україна. 
Шаравара ^. П., канА. меА. наук, старший викладач каф. загальної гігієни та екології, Запорізький державний медичний університет, Україна.

Нефьодов О. О., канА. меА. наук, Аоцент каф. фармакологіі і клінічної фармакології, $\mathrm{A} 3$ "Аніпропетровська медична академія М03 України", м. Аніпро.

Нефьодова О. О., А-р меА. наук, Аоцент, зав. каф. кмінічної анатомії, анатомії та оперативної хірургії, $A 3$ "Аніпропетровська медична академія М03 України", м. Аніпро.

Шаторна В. Ф., А-р біол. наук, професор, зав. каф. медичної біології, фармакогнозії та ботаніки, $A 3$ "Аніпропетровська медична академія М03 України", м. Аніпро.

\section{Сведения об авторах:}

Севальнев А. И., канА. меА. наук, Аоцент, зав. каф. общей гигиены и экологии, Запорожский государственный меАицинский университет, Украина.

Шаравара $\Lambda$. П., канА. меА. наук, старший преподаватель

каф. общей гигиены и экологии, Запорожский государственный меАицинский университет, Украина.

Нефедов А. А., канА. меА. наук, Аоцент каф. фармакологии и клинической фармакологии, ГУ "Анепропетровская медицинская академия МЗ Украины", г. Анипро.

Нефедова Е. А., А-р меА. наук, Аоцент, зав. каф. клинической анатомии, анатомии и оперативной хирургии,

ГУ "Анепропетровская медицинская академия МЗ Украины", г. Анипро.

Шаторная В. Ф., А-р биол. наук, профессор,

зав. каф. медицинской биологии, фармакогнозии и ботаники, гу "Анепропетровская медицинская академия МЗ Украины", г. Анипро.

Conflicts of Interest: authors have no conflict of interest to declare. Конфмікт інтересів: віАсутній.

Надійшла Ао редакції / Received: 26.10.2017

Після Аоопрацювання / Revised: 31.10.2017

Прийнято Ао Аруку / Accepted: 08.11.2017 